\title{
Saving Money for a Better Life: What Can the ABLE Act Do for Me?
}

The "Achieving a Better Life Experience" Act, or ABLE Act, is a federal law that was passed in 2014. It gives people who have a disability a way to save money. This landmark legislation offers people living with disabilities, including those with serious mental health conditions, a chance to pursue their hopes and dreams in a realistic way without as many financial obstacles.

\section{Why is ABLE a big deal for me?}

The ABLE Act is important for young adults living with mental health conditions because it allows them to save money for "qualifying expenses" such as a car, college, training, healthcare, prevention and wellness, and other eligible expenses without being taxed by the government. Such opportunities can allow you to have more independence and a better quality of life. An ABLE account is an easier way to access your savings compared to other types of savings accounts.

- You can put up to $\$ 14,000$ a year into your ABLE account.

- If you are a Supplemental Security Income (SSI) recipient, you can save up to $\$ 100,000$ in an ABLE account without losing your SSI benefits!

- Your Medicaid eligibility and other public benefits (e.g., foodstamps, housing assistance) are not affected by having an ABLE account.

- The total maximum amount that can be put into an ABLE account varies by state, but they are generous, ranging from $\$ 200,000$ to $\$ 400,000$ !

- Save money without getting taxed on any interest that's accrued.

- The money in an ABLE account earns interest, so it can grow!

\section{Who is eligible for an ABLE account?}

In order to be eligible to open an ABLE, you must:

1. Have a physical or psychiatric disability

2. Have become disabled before the age of 26 years old, and

3. Either:
a. Collect Supplemental Security Income (SSI) OR

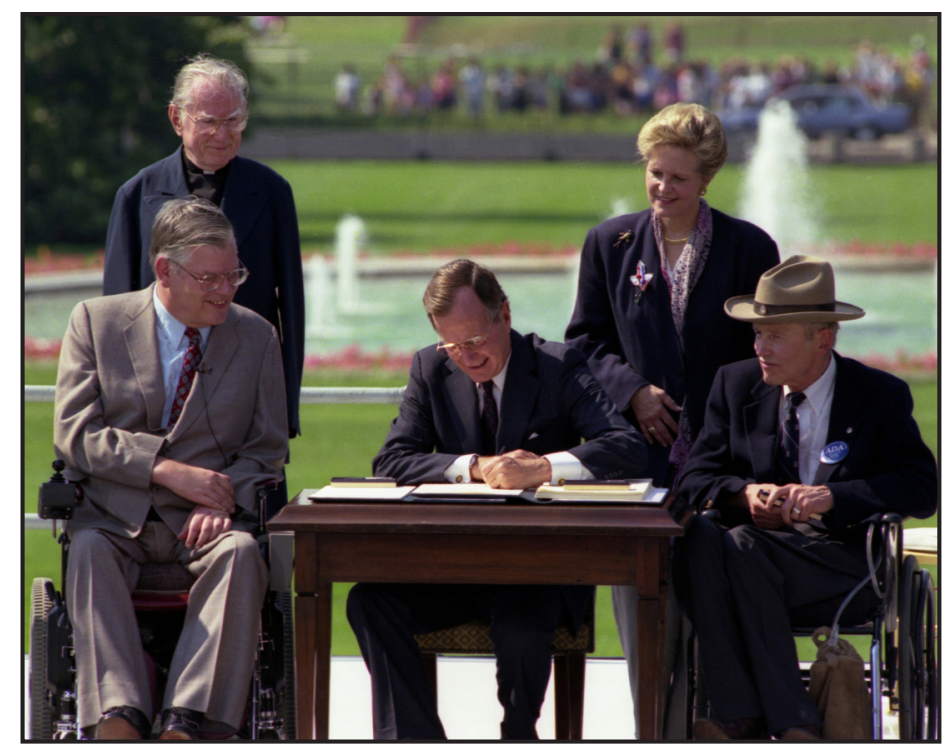

President George Bush signing into law the Americans with Disabilities Act. L to R, sitting: Evan Kemp, Chairman, Equal Employment Opportunity Commission, Justin Dart, Chairman, President's Committee on Employment of People with Disabilities. $L$ to R, standing: Rev. Harold Wilke and Swift Parrino, Chairperson, National Council on Disability.

b. Complete a disability certification form from the IRS that documents your disability (for example, a primary mental health condition that meets the definition of SSI). OR

c. Be a recipient of childhood disability benefits, disability insurance benefits or disabled widow's or widower's benefits based on disability or blindness.

Note: Not all states have an active ABLE program yet. States may have different rules about how to get a disability certification; some states just need some kind of doctor's note that talks about your disability while others need a form completed by you and your doctor. 


\section{How can I open an ABLE account?}

If under 18, talk to your parents or guardian about opening an ABLE account. If 18 or over, you can open one for yourself. To open an ABLE account, you or your representative payee must provide:

1. Your name, Social Security number, date of birth, etc.

2. Your contact information (legal/mailing address, email address, phone number)

3. Employment information of the beneficiary, if applicable (occupation, employer's name and address)

- If someone else is opening the account for the beneficiary then all of the above information is needed for that person as well

- If applicable, Legal Guardianship and/or Power of Attorney documentation will be needed

If you or someone else plans to transfer funds electronically (where available) into the ABLE account, you will need your bank account and routing numbers. Be aware that each state's ABLE program may differ with what documents they need from you!

If you are ready to start an account, go here: http://www.ablenrc.org/state-review

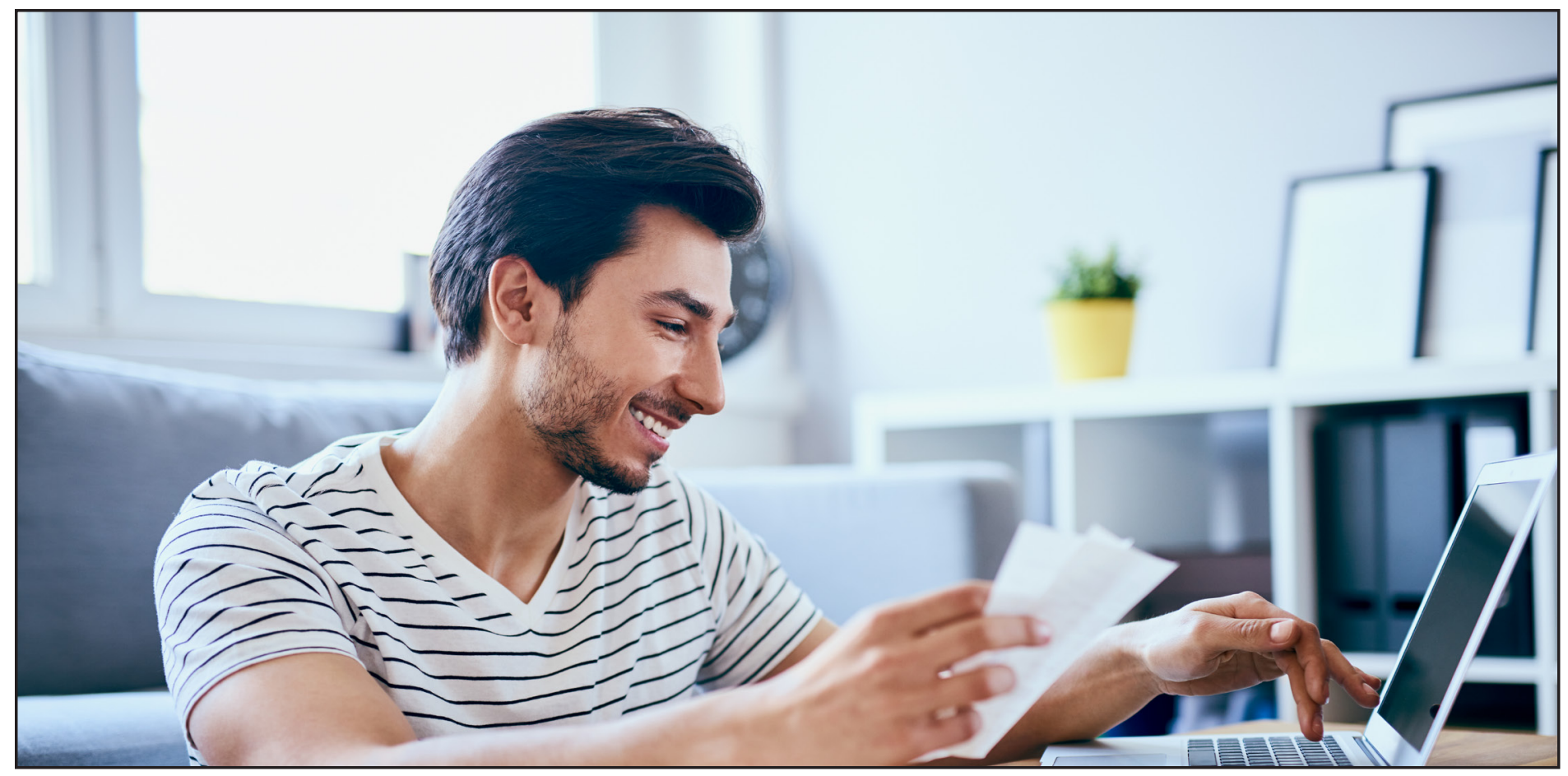

\section{Difference across the United States}

Over 20 states (and counting) have active ABLE programs and are offering ABLE accounts. These state programs can vary in several ways including their minimum deposit fees, and whether or not they have state income tax deductions. Also, some states allow out-of-state people to open ABLE accounts and others do not. You may be able to transfer an out-of-state account to your state when the ABLE program becomes active there. Each state program should have its own website where you can learn more.

Use these websites to see which states have active ABLE programs and how the state programs differ:

- http://www.ablenrc.org/state-review

- http://www.ablenrc.org/state_compare 


\section{ABLE Mrth-Busters}

\section{MYTH}

\section{MYTH BUSTER}

You can lose your ABLE account if you have lied about your disability to the IRS.

Although you can directly deposit your paycheck into an ABLE account, any money that you earn has to be taxed before it can be added.

ABLE account and avoid paying any taxes.

I can have more than one ABLE account at the same time.

No one is allowed more than one ABLE account at the same time. However, it is possible to transfer to a new account if one wants to move from one state to another. Fees may be involved with this.

You need to have the onset of a disability (with documentation as proof) before the age of 26 to qualify for an ABLE account.

for an ABLE account.

The only person who can deposit into the ABLE account is the owner of the account.

The family or friends of the account holder may also make deposits into the account.

Since the ABLE program is set up through the state, it is done through the online portal at the ABLE National Resource Center (link: http://www.ablenrc. org/state-review) or via mail or fax. account.

ABLE accounts are not free; they usually require monthly fees, or minimum amounts that need to be deposited into the account, debit card fees, etc. Fees vary per state program.

Individuals can have both an ABLE account and a living trust.

child who also has a living trust

\section{Parental/payee involvement}

Your family and friends are able to make contributions to your ABLE Account! Like with Supplemental Security Income (SSI) accounts, ABLE accounts can have designated payees if you need someone to have access to your account, and/or so that others are able to deposit a monetary gift into the account. However, there are some guidelines in place to avoid fraud with your ABLE account:

1. You can open an ABLE account yourself or have a representative payee set up and manage one for you.

2. In order for someone to be your payee, they need to either be your parent, legal guardian, or have Power of Attorney for you, which is different from the requirements for SSI Payees.

Having a Representative Payee that you trust is important when you are under 18 years old or are otherwise unable to open an ABLE account on your own. Be aware that you may need to report how to use ABLE funds. 


\section{Can I have a job with an ABLE account?}

Employment does not disqualify you from receiving SSI or opening an ABLE account, but work income will reduce your SSI amount. Opening an ABLE account does not affect your eligibility to receive SSI either. But, having more than $\$ 2,000$ in savings outside of an ABLE account will affect your SSI. It's important to keep your ABLE account balance limit in mind! Having more than $\$ 100,000$ in your ABLE account can affect your standing with SSI. The Social Security Administration offers guidance on how using an ABLE account can impact SSI benefits here: https://secure.ssa.gov/ poms.nsf/lnx/0501130740. Make sure you keep records of you ABLE account expenses, so that you can report them to the SSA.

\section{What is reported to the IRS?}

If a family member wants to deposit money into an ABLE account as a gift, they would not have to pay taxes to the IRS on the money that they add into the ABLE account. Any money that is put into the account by someone that is not the account owner isn't considered income so you wouldn't have to pay taxes on any gifts you receive from friends or family.

Also, while the list of things you can spend your ABLE money on is very broadly defined, you will be charged taxes if money is taken out of the ABLE account for something that is not a 'qualified expense.' In that case, you would need to pay a $10 \%$ tax penalty.

\section{Resources}

ABLE National Resource Center: http://www.ablenrc.org/

ABLE Accounts: 10 Things You Should Know: http://www.ablenrc.org/about/what-are-able-accounts

Social Security Agency: https://secure.ssa.gov/poms.nsf/lnx/0501130740

IRS FAQ on Gift Taxes: https://www.irs.gov/businesses/small-businesses-self-employed/frequently-asked-questions-ongift-taxes

National Down Syndrome Society FAQ about ABLE: https://www.ndss.org/Global/Policy/ABLE/TheABLEAct-

FrequentlyAskedQuestions-web.pdf

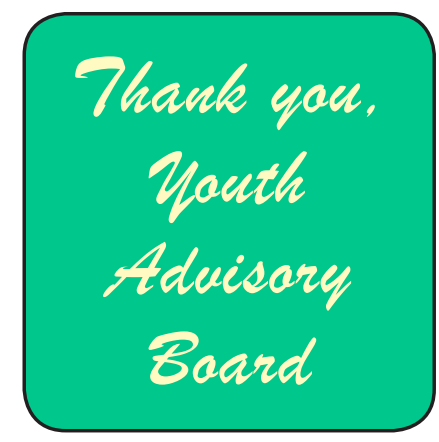

\section{Acknowledgements}

The Transitions RTC would like to send a very special thanks to our National Youth Advisory Board! Without your questions, suggestions and edits, this tip sheet would not have been possible!

Since early 2014, The RTC's National Youth Advisory Board (YAB) has provided youth voice and incorporated young adult feedback in the research projects and products of the Transitions RTC and the Systems and Psychosocial Advances Research Center (SPARC).

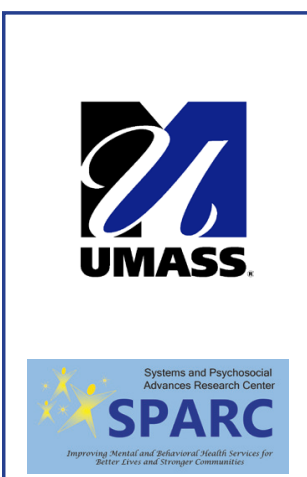

Suggested citation: Mizrahi, R., Duperoy, T., Youth Advisory Board of the Transitions RTC; \& Logan, D. (2017). Saving Money for A Better Life: What Can the ABLE Act Do for Me? Worcester, MA: University of Massachusetts Medical School, Department of Psychiatry, Systems and Psychosocial Advances Research Center (SPARC), Transitions Research and Training Center.

This publication can be made available in alternative formats upon request through TransitionsRTC@umassmed.edu

The contents of this tipsheet were developed under a grant with funding from the National Institute on Disability, Independent Living, and Rehabilitation Research, and from the Center for Mental Health Services of the Substance Abuse and Mental Health Services Administration, United States Department of Health and Human Services (ACL Grant\# 90RT5031, The Learning and Working Transitions RRTC). NIDILRR is a Center within the Administration for Community Living (ACL), Department of Health and Human Services (HHS). The contents of this tipsheet do not necessarily represent the policy of NIDILRR, ACL, HHS, or SAMHSA and you should not assume endorsement by the Federal Government.

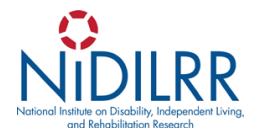

SAMHSA

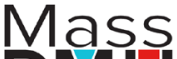
DMH 